\title{
Inhibitory effect of a TGF $\beta$ receptor type-I inhibitor, Ki26894, on invasiveness of scirrhous gastric cancer cells
}

\author{
O Shinto', M Yashiro*, 1,2, H Kawajiri', K Shimizu³, T Shimizu4, A Miwa ${ }^{5}$ and K Hirakawa' \\ 'Department of Surgical Oncology, Osaka City University Graduate School of Medicine, Osaka, Japan; ${ }^{2}$ Oncology Institute of Geriatrics and Medical \\ Science, Osaka City University Graduate School of Medicine, Osaka, Japan; ${ }^{3}$ Pharmacological Research Laboratories, Kyowa Hakko Kirin Co Ltd, Gunma, \\ Japan; ${ }^{4}$ Research Planning Department, Kyowa Hakko Kirin Co Ltd, Gunma, Japan; ${ }^{5}$ Drug Discovery Research Laboratories, Kyowa Hakko Kirin Co Ltd, \\ Gunma, Japan
}

BACKGROUND: Gastric cancer cells frequently metastasise, partly because of their highly invasive nature. Transforming growth factor- $\beta$ (TGF- $\beta$ ) receptor signalling is closely associated with the invasion of cancer cells. The aim of this study was to clarify the effect of a TGF- $\beta$ receptor (T $\beta$ R) phosphorylation inhibitor on the invasiveness of gastric cancer cells.

METHODS: Four gastric cancer cell lines, including two scirrhous-type cell lines and two non-scirrhous-type cell lines, were used. A T $\beta R$ type I (T $\beta$ R-I) kinase inhibitor, Ki26894, inhibits the phosphorylation of Smad2 at an ATP-binding site of T $\beta$ R-I. We investigated the expression levels of T $\beta R$ and phospho-Smad2, and the effects of TGF- $\beta$ in the presence or absence of Ki26894 on Smad2 phosphorylation, invasion, migration, epithelial-to-mesenchymal transition (EMT), Ras homologue gene family member A (RhoA), ZO-2, myosin, and E-cadherin expression of gastric cancer cells.

RESULTS: T $\beta$ R-I, T $\beta$ R-II, and phospho-Smad2 expressions were found in scirrhous gastric cancer cells, but not in non-scirrhous gastric cancer cells. Ki26894 decreased Smad2 phosphorylation induced by TGF- $\beta$ I in scirrhous gastric cancer cells. Transforming growth factor- $\beta$ I upregulated the invasion, migration, and EMT ability of scirrhous gastric cancer cells. Transforming growth factor- $\beta$ I significantly upregulated the activity of RhoA and myosin phosphorylation, whereas TGF- $\beta$ I decreased ZO- 2 and E-cadherin expression in scirrhous gastric cancer cells. Interestingly, Ki26894 inhibited these characteristics in scirrhous gastric cancer cells. In contrast, non-scirrhous gastric cancer cells were not affected by TGF- $\beta$ | or Ki26894 treatment.

CONCLUSION: A T $\beta$ R-I kinase inhibitor decreases the invasiveness and EMT of scirrhous gastric cancer cells. Ki26894 is therefore considered to be a promising therapeutic compound for the metastasis of scirrhous gastric carcinoma.

British Journal of Cancer (2010) 1 02, 844-85I. doi:I0.1038/sj.bjc.660556I www.bjcancer.com

Published online 9 February 2010

(C) 2010 Cancer Research UK

Keywords: scirrhous gastric cancer; TGF- $\beta$; epithelial-to-mesenchymal transition; Smad2; phosphorylation inhibitor

There are two types of gastric cancer: diffuse type and intestinal type, according to the Laurén classification (Lauren, 1965). Scirrhous gastric carcinoma, also called diffuse-type gastric carcinoma, or linitis plastica, is characterised by a diffusely infiltrating growth accompanied by extensive stromal fibrosis and a high frequency of metastasis to the lymph nodes and the peritoneum (Yokota et al, 1999; Nakazawa et al, 2003), resulting in an extremely poor prognosis (Otsuji et al, 2004; Kunisaki et al, 2005). The high invasive ability of cancer cells is responsible for the diffusely infiltrating growth and frequent metastatic spread of scirrhous gastric carcinoma.

Transforming growth factor- $\beta$ (TGF- $\beta$ ) signals have an important role in the metastatic spread of cancer cells (Saito et al, 2000; Massague, 2008; Yang and Moses, 2008), such as

*Correspondence: Dr M Yashiro, Department of Surgical Oncology, Osaka City University Graduate School of Medicine, 1-4-3 Asahimachi, Abeno-ku, Osaka 545-8585, Japan;

E-mail:m9312510@med.osaka-cu.ac.jp

Received 28 September 2009; revised 6 January 2010; accepted II January 2010; published online 9 February 2010 migration, invasion, and epithelial-to-mesenchymal transition (EMT) (Thiery, 2002; Massague, 2008). Overexpression of TGF- $\beta$ is reported to be correlated with poor prognosis of gastric tumours (Saito et al, 2000), especially scirrhous gastric carcinoma (Kinugasa et al, 1998), suggesting that TGF- $\beta$ signalling might have an important role in the progression of scirrhous gastric cancer cells (Inoue et al, 1997; Kinugasa et al, 1998; Kawajiri et al, 2008). Therefore, inhibition of TGF- $\beta$ signalling in scirrhous gastric carcinoma may yield beneficial effects through inhibition of invasion and metastasis of cancer. Although there are several reports of molecular target therapies against TGF- $\beta$ signalling from the viewpoint of adhesion (Kano et al, 2007; Kawajiri et al, 2008), proliferation (Tateishi et al, 2000; Komuro et al, 2009), or angiogenesis (Kano et al, 2007; Kawajiri et al, 2008) in scirrhous gastric carcinoma, the effectiveness of TGF- $\beta$ signalling inhibitor on invasion and migration has not been proposed in this type of carcinoma. Transforming growth factor- $\beta$ activates TGF- $\beta$ receptor type II (T $\beta$ R-II), which phosphorylates TGF- $\beta$ receptor type I (T $\beta$ R-I) (Heldin et al, 1997; Massague, 2008). Activated T $\beta$ RI kinase phosphorylates $\operatorname{Smad} 2 / 3$, which are associated with Smad4 and translocation in the nucleas as transcriptional factors (Heldin et al, 1997; Massague, 2008). In this study, we investigated the 
effect of a novel T $\beta$ R-I inhibitor Ki26894 on the invasiveness of gastric cancer.

\section{MATERIALS AND METHODS}

\section{Compounds}

A small synthetic molecule that interrupts the phosphorylation of Smad2/Smad3 by T $\beta$ R-I, namely, Ki26894, was synthesised by Kirin Brewery Company (Gunma, Japan) as previously reported (Ehata et al, 2007). Ki26894 was dissolved in PBS (Nikken Bio., Kyoto, Japan), stored at $4{ }^{\circ} \mathrm{C}$, and used within 5 days. Transforming growth factor- $\beta 1$ was purchased from R\&D Systems (Minneapolis, MN, USA).

\section{Cell lines}

OCUM-2MLN (Fujihara et al, 1999) and OCUM-12 (Qiu et al, 2009) were derived from scirrhous gastric carcinomas. MKN-45 (Motoyama et al, 1986) and MKN-74 (Motoyama et al, 1986) were derived from non-scirrhous gastric carcinomas. The culture medium consisted of DMEM (Nikken Bio.) with the addition of $10 \%$ heat-inactivated fetal bovine serum (FBS; Equitech-Bio, Kerrville, TX, USA), $100 \mathrm{IU} \mathrm{m}^{-1}$ penicillin (ICN Biomedicals, Costa Mesa, CA, USA), $100 \mu \mathrm{g} \mathrm{ml}^{-1}$ streptomycin (ICN Biomedicals), and $0.5 \mathrm{~mm}$ sodium pyruvate (Cambrex, Walkersville, MD, USA). Cells were cultured at $37^{\circ} \mathrm{C}$ in a humidified atmosphere containing $5 \% \mathrm{CO}_{2}$ in the air.

\section{Morphological findings}

Cancer cells were also cultured with TGF- $\beta 1\left(10 \mathrm{ng} \mathrm{ml}^{-1}\right)$ and/or Ki26894 $(0.1,0.3,1,3$, or $10 \mu \mathrm{M})$. Cell morphology was observed microscopically, 24,48 , and $72 \mathrm{~h}$ after addition.

\section{Wound healing assay}

In vitro wound healing ability was measured by the method described in the study by Borensztajn et al (2008), with some modifications. Gastric cancer cells were cultured in six-well plates. After the cells reached semi-confluence, a wound was created in the cell monolayer using a pipette tip. Cancer cells were cultured in serum-free DMEM, along with TGF- $\beta 1\left(10 \mathrm{ng} \mathrm{ml}^{-1}\right)$ and/or Ki26894 $(10 \mu \mathrm{M})$. Four scratched fields were randomly chosen and the number of cell migrations was counted from pictures $24 \mathrm{~h}$ after treatment.

\section{Invasion assay}

In vitro invasiveness was measured by the method described in the study by Albini et al (1987), with some modifications. We used chemotaxis chambers with a $12 \mu \mathrm{m}$-pore membrane filter (Kubota, Osaka, Japan) coated with $50 \mu \mathrm{g}$ of matrigel in a 24 -well culture plate. Gastric cancer cells $\left(2 \times 10^{3}\right.$ cells per chamber $)$ were seeded, and TGF- $\beta 1$ (a final concentration of 0 or $10 \mathrm{ng} \mathrm{ml}^{-1}$ ) and/or $\mathrm{Ki} 26894$ (a final concentration of $0,0.1,1$, or $10 \mu \mathrm{M}$ ) were added to the upper chambers. After $72 \mathrm{~h}$ incubation, cells that had not moved to the lower wells were removed from the upper face of the filters using cotton swabs, and the cells that had moved to the lower surface of the filter were stained with haematoxylin. Cancer cells that invaded through a filter coated with matrigel to the lower surface of the membrane were manually counted under a microscope at $\times 200$ magnification. The mean of six fields was calculated as the sample value. The culture was performed in triplicate.

\section{Immunohistochemistry}

BALB/c nude female mice, aged 4 weeks (Nihon CLEA, Tokyo, Japan), were used in the studies. All experiments were performed according to the standard guidelines for animal experiments of Osaka City University Medical School. The expression of T $\beta \mathrm{R}-\mathrm{I}$, $\mathrm{T} \beta \mathrm{R}-\mathrm{II}$, and phosphorylated Smad2 of xenografts was examined. Xenografts were established by injecting each cell $\left(1 \times 10^{7}\right)$ into the flanks of nude mice. Four weeks after inoculation, mice were killed, and the xenografted tumours were washed in PBS and fixed in $10 \%$ formalin for paraffin sectioning. Immunohistochemical determination of T $\beta \mathrm{R}-\mathrm{I}, \mathrm{T} \beta \mathrm{R}-\mathrm{II}$, and phosphorylated Smad 2 was carried out according to the manufacturer's instructions. In brief, slides were deparaffinised, and were heated for $10 \mathrm{~min}$ at $105^{\circ} \mathrm{C}$ by autoclave in Target Retrieval Solution (Dako, Carpinteria, CA, USA). The sections were then incubated with $3 \%$ hydrogen peroxide to block endogenous peroxidase activity. The specimens were incubated with anti-T $\beta$ R-I antibody (Lab vision, Fremont, CA, USA; $1: 100$ ), anti-T $\beta$ R-II antibody (Lab vision; $1: 100$ ), and anti-phospho-Smad2 antibody (Chemicon International, Themecula, CA, USA; $1: 2000)$ overnight at $4{ }^{\circ} \mathrm{C}$. The sections were incubated with biotinylated goat anti-rabbit immunoglobulin $\mathrm{G}$ for $30 \mathrm{~min}$. The slides were treated with streptavidin-peroxidase reagent, and were incubated in PBS diaminobenzidine and $1 \%$ hydrogen peroxide $\mathrm{v} / \mathrm{v}$, followed by counterstaining with Mayer's haematoxylin.

\section{Western blot analysis}

The inhibition by Ki26894 of the phosphorylation of Smad2 and its migration ability in gastric cancer cells were examined by western blotting. Briefly, cell lines were cultured in DMEM with 2\% FBS for 2 days. The culture was rinsed with PBS and incubated in serumfree DMEM with reagent (TGF- $\beta 1$ : a final concentration of 0 or $10 \mathrm{ng} \mathrm{ml}^{-1}$; Ki26894: a final concentration of $0,0.1,0.3,1,3$, or $10 \mu \mathrm{M}$ ) for $60 \mathrm{~min}$. The cells were lysed in a lysis buffer. Aliquots containing $30 \mu \mathrm{g}$ of total protein were subjected to SDS-PAGE, and the protein bands were transferred to a polyvinylidene difluoride membrane (Amersham, Aylesbury, UK). The membrane was kept in TBS-T (10 mM TBS and $0.05 \%$ Tween 20 ) supplemented with $5 \%$ non-fat milk or $5 \%$ bovine albumin (Sigma, St Louis, MO, USA) at room temperature for $1 \mathrm{~h}$. Next, the membrane was placed in a TBS-T solution containing each primary antibody. The membrane was placed in TBS-T solution containing the primary antibody, phospho-Smad2 (Cell Signaling Tec, Danvers, CO, USA, Ser 465/467; $1: 1000$ ), Smad2/3 (Cell Signaling Tec; $1: 1000$ ), ZO-2 (Cell Signaling Tec; $1: 1000$ ), phospho-myosin light chain-2 (Cell Signaling Tec, Thr18/Ser19; 1:1000), E-cadherin (Cell Signaling Tec; $1: 1000$ ), or $\beta$-actin (Cell Signaling Tec; $1: 1000$ ), and allowed to react at $4{ }^{\circ} \mathrm{C}$ overnight for western blotting. Next, each antibody was washed three times with TBS-T for $10 \mathrm{~min}$, and a peroxidaselabelled secondary antibody (Amersham) reactive with the primary antibody was added. The membrane was placed in the TBS-T solution, kept at room temperature for $1 \mathrm{~h}$, and then washed. Bands were detected using an enhanced chemiluminescence system (Amersham). An immunoblot analysis was performed twice. PANC-1, a pancreas cancer cell line, was used as the positive control of Smad2 (Romero et al, 2008; Horiguchi et al, 2009).

\section{Ras homologue gene family member A activation assay}

Activated Ras homologue gene family member A (RhoA) proteins were measured with a RhoA activation G-LISA (Absorbance Based) assay kit (Cytoskeleton, Denver, CO, USA) according to the manufacturer's instructions. The activation of RhoA by TGF- $\beta 1$ and the inhibition by Ki26894 in gastric cancer cells were examined as follows. Cell lines were cultured in DMEM with $2 \%$ FBS. The culture was rinsed with PBS and incubated in serum-free 
DMEM with reagent (TGF- $\beta 1$ : a final concentration of 0 or $10 \mathrm{ng} \mathrm{ml}^{-1}$; Ki26894: a final concentration of 0 or $10 \mu \mathrm{M}$ ) for $10 \mathrm{~min}$. Activation of RhoA analysis was performed for the third time.

\section{Statistical analysis}

Comparisons among data sets were made with the Kruskal-Wallis one-way ANOVA by ranks, followed by Dunn's multiple comparison test. A difference was considered significant when the $P$-value was 0.05 or less.

\section{RESULTS}

Expression of T $\beta$ R-I, T $\beta$ R-II, and phospho-Smad 2 in gastric cancer cells

Figure 1A shows the expression level of $\mathrm{T} \beta \mathrm{R}-\mathrm{I}, \mathrm{T} \beta \mathrm{R}-\mathrm{II}$, and phospho-Smad2 of gastric cancer cells in xenografted tumours. $\mathrm{T} \beta \mathrm{R}-\mathrm{I}$ and $\mathrm{T} \beta \mathrm{R}$-II were immunolocalised at the membrane and cytoplasm, respectively, of gastric cancer cells. High expression levels of $\mathrm{T} \beta \mathrm{R}-\mathrm{I}$ and $\mathrm{T} \beta \mathrm{R}-\mathrm{II}$ were found in scirrhous gastric cancer cells (OCUM-2MLN and OCUM-12), but not in non-scirrhous gastric cancer cells (MKN-45 and MKN-74). Phospho-Smad2 was expressed in the nucleus of scirrhous gastric cancer cells. The overexpression of phospho-Smad2 was observed in scirrhous gastric cancer cells, but not in non-scirrhous gastric cancer cells.

\section{Effects of Ki26894 on Smad2 phosphorylation in gastric cancer cells}

To determine whether the small-molecule compound, Ki26894, inhibits TGF- $\beta$ signalling, the effect of Ki26894 on TGF- $\beta$-induced
Smad2 phosphorylation was examined in gastric cancer cells. Smad 2 phosphorylation was increased by TGF- $\beta 1\left(10 \mathrm{ng} \mathrm{ml}^{-1}\right)$ in scirrhous gastric cancer cell lines, OCUM-2MLN and OCUM-12. Smad2 phosphorylation was decreased in a dose-dependent manner by Ki26894 from 3 to $10 \mu \mathrm{M}$. In contrast, Smad2 phosphorylation was not detected with TGF- $\beta 1$ treatment in non-scirrhous gastric cancer cell lines, $\mathrm{MKN}-45$ and $\mathrm{MKN}-74$ (Figure 1B, 1C).

\section{Ki26894 reduces the migration of scirrhous gastric cancer cells induced by TGF- $\beta$}

Figure $2 \mathrm{~A}$ is a representative phase-contrast photograph of OCUM-2MLN cells. The number of migrating OCUM-2MLN cells was increased by TGF- $\beta 1\left(10 \mathrm{ng} \mathrm{ml}^{-1}\right)$ and was decreased in the presence of Ki26894 $(10 \mu \mathrm{M})$. The migrating ability of OCUM-12 cells was increased in the presence of TGF- $\beta 1$ (Supplementary Movie 1), compared with the control (Supplementary Movie 2). Transforming growth factor- $\beta 1$ significantly stimulated the migration of OCUM-2MLN $(P<0.001)$ and OCUM-12 cells $(P=0.004)$. Ki26894 significantly inhibited the migration-stimulating ability of TGF- $\beta 1$ in both OCUM-2MLN $(P<0.001)$ and OCUM-12 cells $(P=0.006)$. In contrast, neither TGF $\beta 1$ nor Ki26894 affected migration by the non-scirrhous gastric cancer cell lines used (Figure 2B).

\section{Effect of Ki26894 on scirrhous gastric cancer cell invasion}

Figure $3 \mathrm{~A}$ is a representative phase-contrast photograph of OCUM-12 cells that have invaded into a $12-\mu \mathrm{m}$-pore membrane filter. The number of OCUM-12 cells displaying EMT was significantly increased in the presence of TGF- $\beta 1$ when compared with the control. The migration-stimulating activity of TGF- $\beta 1$ was

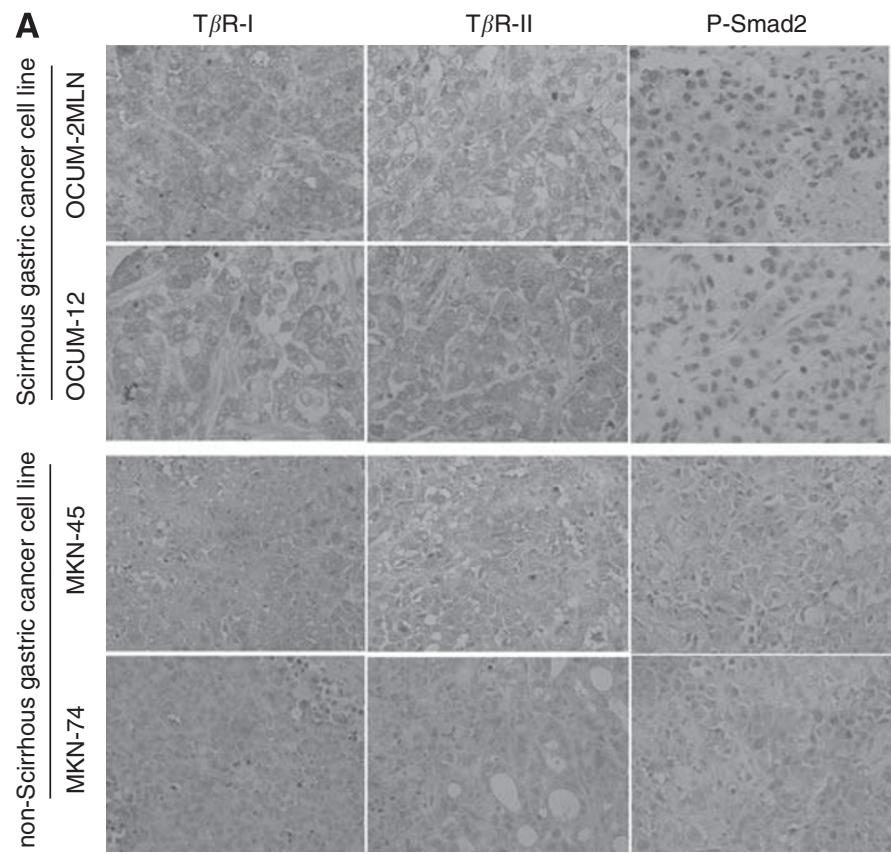

B

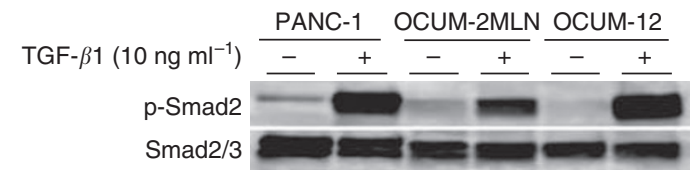

C

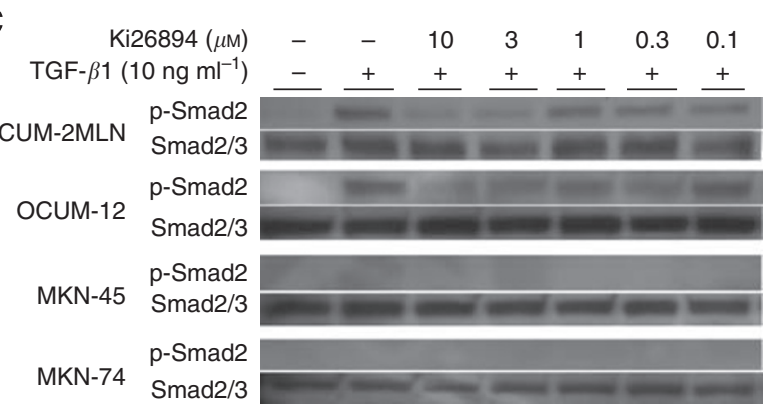

Figure I Expression of TGF- $\beta$ signalling and inhibitory effect of Ki26894. (A) Expression level of TGF- $\beta$ receptor and phospho-Smad2. The overexpression of TGF- $\beta$ receptor type I (T $\beta \mathrm{R}-\mathrm{I})$, type II (T $\beta \mathrm{R}-\mathrm{II})$, and phospho-Smad2 (P-Smad2) was observed in scirrhous gastric cancer cell lines, OCUM-2MLN and OCUM- I2, but not in non-scirrhous gastric cancer cell lines, MKN-45 and MKN-74. (B, C) Effects of Ki26894 on TGF- $\beta$-induced Smad2 phosphorylation of gastric cancer cells. PANC-I was used as positive control of Smad2 phosphorylation. Transforming growth factor- $\beta$ stimulated Smad2 phosphorylation in PANC-I, OCUM-2MLN, and OCUM-I2 cells. Total Smad2/3 expression was recognised in all four gastric cancer cell lines and no difference in expression level was found on addition of TGF- $\beta$ I or Ki26894. Transforming growth factor- $\beta \mid\left(\mid 0\right.$ ng ml $\left.{ }^{-1}\right)$ stimulated Smad2 phosphorylation in both scirrhous gastric cancer cell lines, but not in non-scirrhous cancer cell lines, MKN-45 and MKN-74. Smad2 phosphorylation was decreased in a dosedependent manner by Ki26894 in scirrhous gastric cancer cell lines. PANC-I, a pancreas cancer cell line, was used as positive control of Smad2. 
A
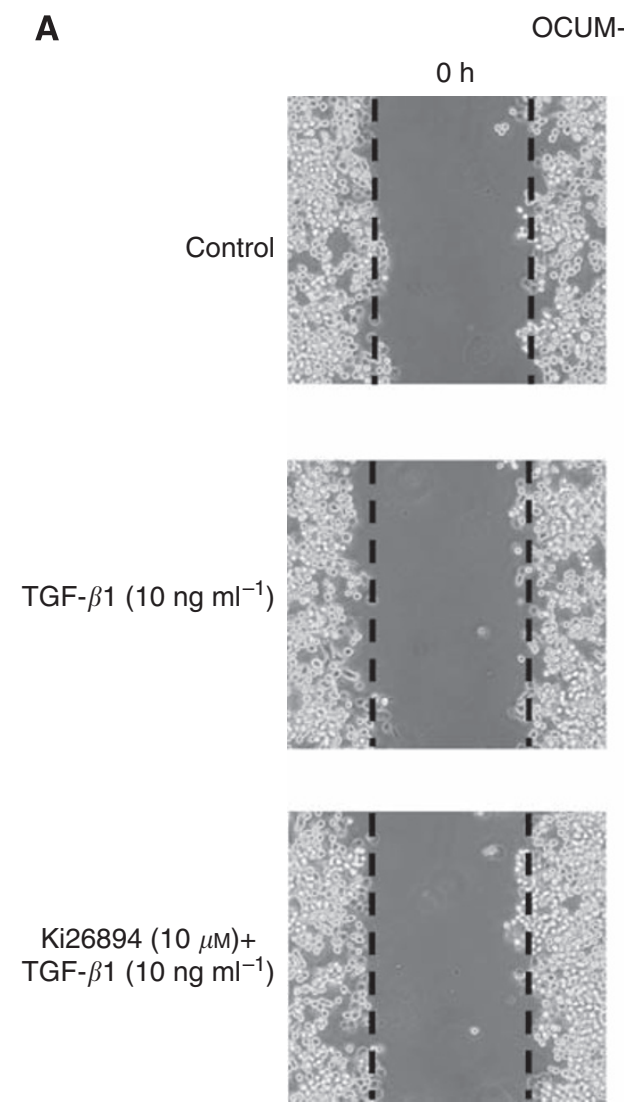

$24 \mathrm{~h}$
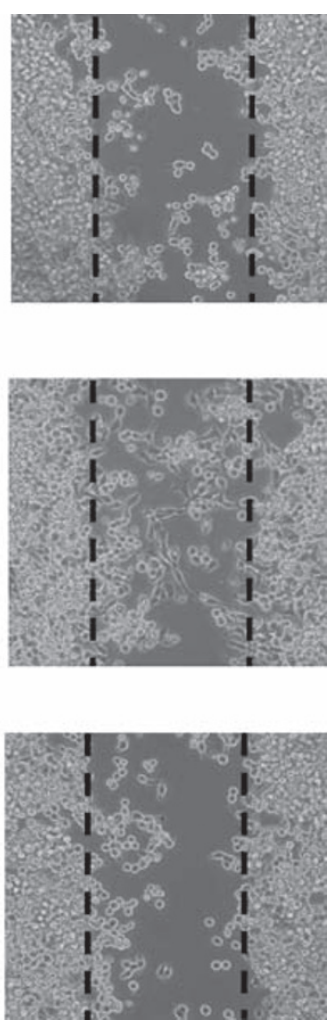

B
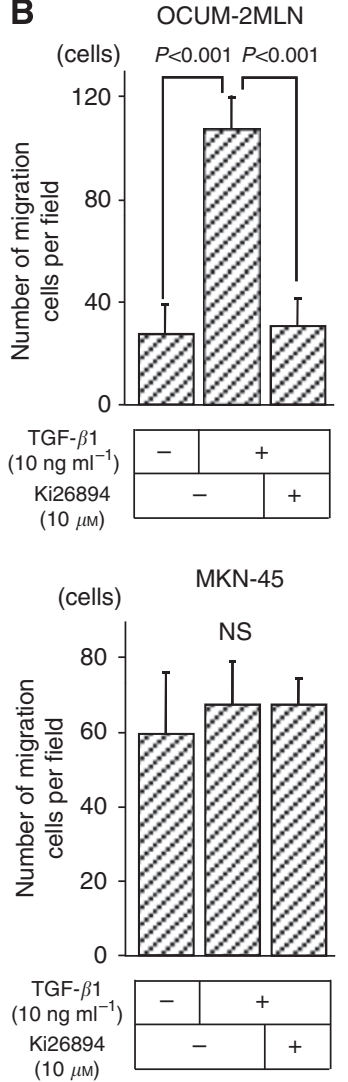

OCUM-12
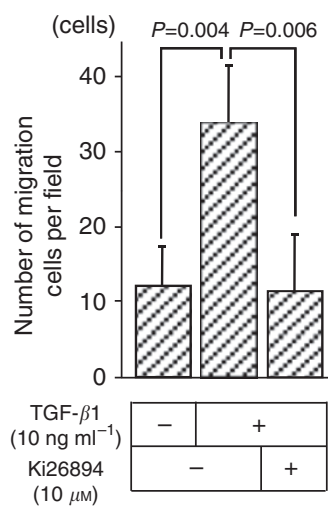

MKN-74
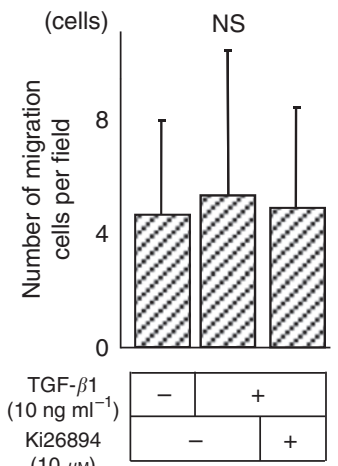

Figure 2 Effect of Ki26894 on the wound healing ability of cancer cells. (A) Representative pictures from three experiments are shown. The number of OCUM-2MLN cells that migrated over the wound line (dotted line) was increased by TGF- $\beta$ I treatment when compared with that of control. The migrating cells displayed spindle shapes characteristic of epithelial-to-mesenchymal transition (EMT). Ki26894 (I $0 \mu \mathrm{M}$ ) downregulated the ability of OCUM-2MLN cells to migrate over a wound line. (B) TGF- $\beta$ I significantly stimulated the migration of scirrhous gastric cancer cells, but not of non-scirrhous gastric cancer cells. Ki26894 (I0 $\mu \mathrm{M})$ significantly inhibited the migration of scirrhous gastric cancer cells.

decreased in the presence of Ki26894 $(10 \mu \mathrm{M})$. Transforming growth factor- $\beta 1\left(10 \mathrm{ng} \mathrm{ml}^{-1}\right)$ significantly stimulated invasion $(P<0.001)$ by scirrhous gastric cancer cell lines, but not by nonscirrhous gastric cancer cell lines. Ki26894 $(10 \mu \mathrm{M})$ significantly $(P<0.001)$ inhibited invasion by scirrhous gastric cancer cells. In contrast, invasion was not affected by TGF- $\beta 1$ or Ki26894 in the non-scirrhous gastric cancer cell lines used (Figure $3 \mathrm{~B}$ ).

\section{Effects of TGF- $\beta 1$ and Ki26894 on the morphological characteristics of gastric cancer cells}

Epithelial-to-mesenchymal transition was found in both scirrhous gastric cancer cell lines (OCUM-12 and OCUM-2MLN) in culture with the addition of TGF- $\beta 1$. An increase in the number of attached and spreading cells was found after the addition of TGF- $\beta 1$, whereas most of the OCUM-2MLN and OCUM- 12 cells without TGF- $\beta 1$ treatment were still round. OCUM-12 cells exhibited loss of cell-cell adhesion and spindle-shaped cells. However, Ki26894 $(10 \mu \mathrm{M})$ inhibited these morphological changes associated with EMT in scirrhous gastric cancer cells. In contrast, non-scirrhous gastric cancer cell lines (MKN-45 and MKN-74) did not display these morphological changes after the addition of TGF- $\beta 1$ (Figure 4 ).

\section{Effects of Ki26894 on cellular signalling pathways exhibited during migration}

Transforming growth factor- $\beta 1$ significantly upregulated the active form of RhoA in scirrhous gastric cancer cell lines, OCUM-2MLN
$(P=0.008)$ and OCUM-12 $(P=0.007)$, when compared with control. However, Ki26894 significantly inhibited the active RhoA induced by TGF- $\beta 1$ in scirrhous gastric cancer cell lines, OCUM-2MLN $(P=0.047)$ and OCUM-12 $(P=0.029)$. In contrast, active RhoA was not affected by TGF- $\beta 1$ or Ki26894 in nonscirrhous cancer cell lines (Figure 5A). Transforming growth factor- $\beta 1\left(10 \mathrm{ng} \mathrm{ml}^{-1}\right)$ decreased ZO-2 and E-cadherin expression in scirrhous gastric cancer cells and increased myosin light chain-2 phosphorylation (p-myosin), but not in non-scirrhous gastric cancer cells. In addition, Ki26894 increased ZO-2 and E-cadherin expression and inhibited p-myosin in scirrhous gastric cancer cells (Figure 5B).

\section{DISCUSSION}

In this study, scirrhous gastric cancer cells expressed $\mathrm{T} \beta \mathrm{R}-\mathrm{I}$ and T $\beta$ R-II. Furthermore, TGF- $\beta$ stimulated the phosphorylation of Smad2 in scirrhous gastric cancer cells as previously reported (Komuro et al, 2009), but not in non-scirrhous gastric cancer cells, suggesting that TGF- $\beta$ signalling is active in scirrhous gastric cancer, but not in non-scirrhous gastric cancer.

Transforming growth factor- $\beta 1$ stimulated EMT in scirrhous gastric cancer cells, but not in non-scirrhous gastric cancer cells. Epithelial-to-mesenchymal transition is characterised by spindleshaped cells with a reduction in epithelial cell markers of cell-cell adhesion molecules (Thiery, 2002; Jung et al, 2006; Revenu and Gilmour, 2009). The expression levels of cell-cell adhesion 
A
OCUM-12
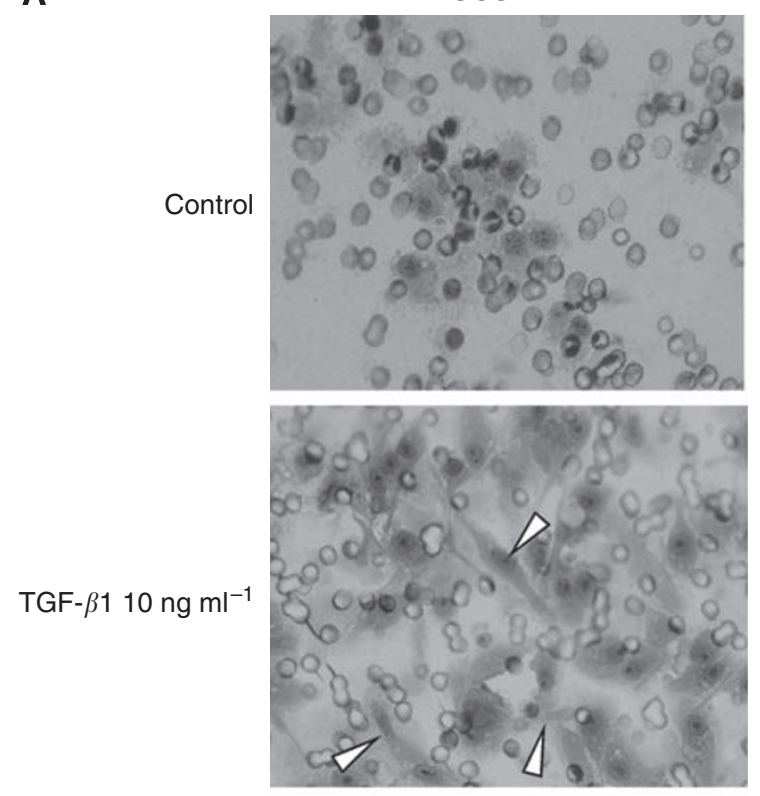

Ki26894 (10 $\mu \mathrm{M})+$ TGF- $\beta 1$ (10 $\mathrm{ng} \mathrm{ml}^{-1}$ )
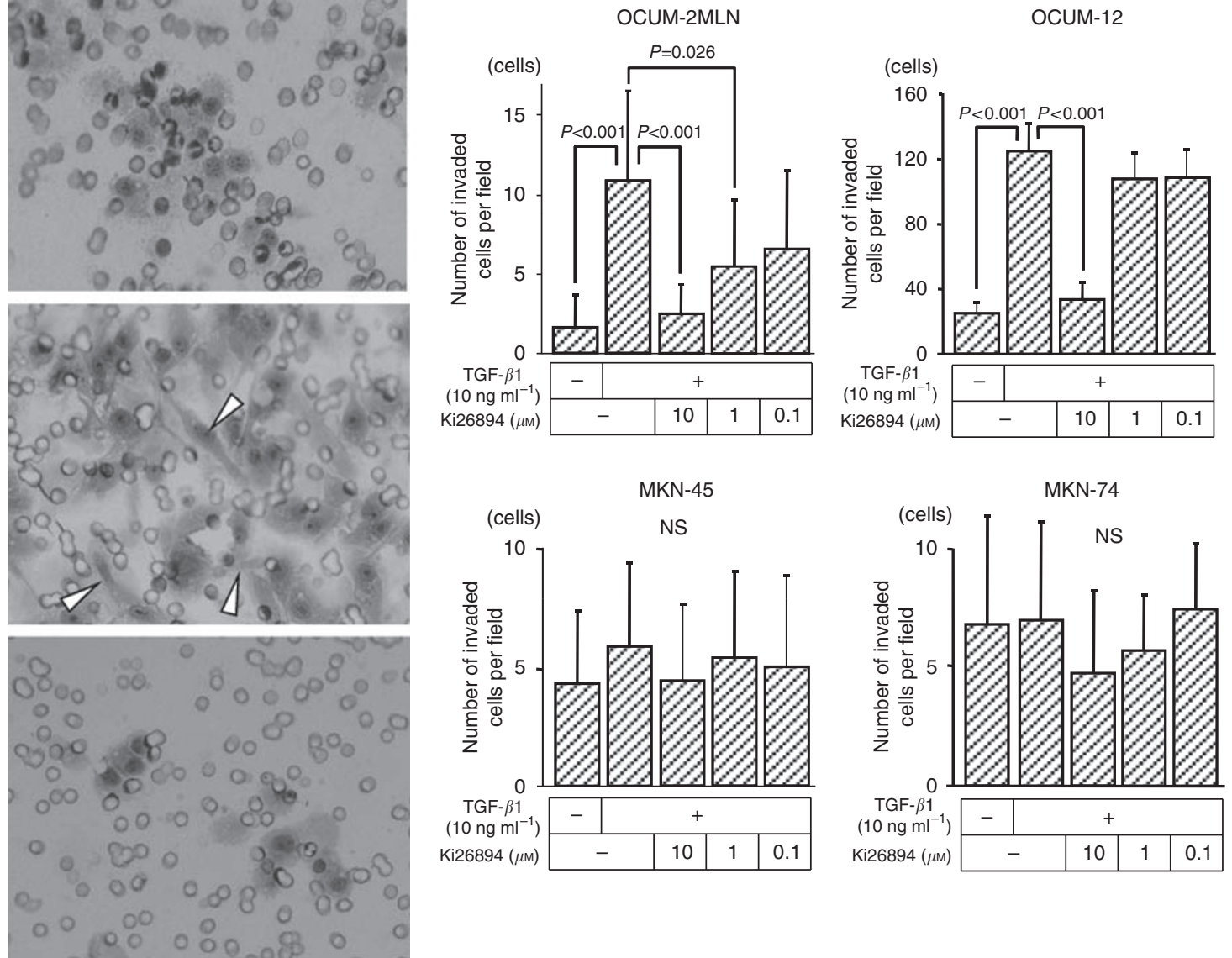

Figure 3 Ki26894 inhibits invasion by scirrhous gastric cancer cells. (A) Representative pictures of invading gastric cancer cells. OCUM- 12 cells invaded into a $12 \mu \mathrm{m}$-pore membrane filter in the presence of TGF- $\beta$ I when compared with control. Most of the invaded cells show epithelial-to-mesenchymal transition (arrow heads). Ki26894 (I0 $\mu \mathrm{M}$ ) inhibited the invasion induced by TGF- $\beta$ I. (B) Transforming growth factor- $\beta$ I significantly stimulated the invasive behaviour of OCUM-2MLN and OCUM-I2 cells. Ki26894 (I0 $\mu \mathrm{M}$ ) significantly inhibited the invasion seen in these cells. In contrast, invasion by non-scirrhous gastric cancer cell lines, MKN-45 and MKN-74, was not affected by TGF- $\beta$ I or by Ki26894.

molecules, ZO-2 and E-cadherin, were downregulated by TGF- $\beta 1$ in scirrhous gastric cancer cells. Moreover, $\mathrm{T} \beta \mathrm{R}$ signalling activates RhoA, which mediates the upregulation of myosin light chain-2 phosphorylation (Shook and Keller, 2003; Fan et al, 2007) and downregulation of cell-cell tight junctions (Takaishi et al, 1997; Yamazaki et al, 2008). Transforming growth factor- $\beta 1$ significantly upregulated active RhoA and phospho-myosin of scirrhous gastric cancer cells. The EMT of scirrhous gastric cancer cells induced by TGF $\beta$ signalling might be mediated by the regulation of RhoA, myosin, $\mathrm{ZO}-2$, and E-cadherin. Scirrhous gastric carcinoma is a diffuse-type gastric cancer characterised by loss of cell-cell adhesion. Transforming growth factor- $\beta$ signalling of downregulation of cell-cell adhesion might be closely associated with the histologenesis of scirrhous gastric carcinoma. Intestinal-type tumours show an expanding growth with definite border according to the Laurén classification (Lauren, 1965). These histological differences between diffuse-type and intestinal-type tumours might be determined in part by the response of gastric cancer cells to TGF $\beta / \mathrm{T} \beta \mathrm{R}$ signalling.

Transforming growth factor- $\beta \mathrm{R}$ signalling increased the migrating ability of scirrhous gastric cancer cells, but not of nonscirrhous gastric cancer cells. Transforming growth factor- $\beta 1$ activates RhoA, which promotes cancer cell invasion and eventually leads to metastasis by disrupting E-cadherin-mediated adherens junctions (Chang et al, 2009). In this study, TGF- $\beta 1$ significantly upregulated active RhoA of scirrhous gastric cancer cells. Ras homologue gene family member A might regulate not only EMT but also migrating ability in scirrhous gastric cancer cells through TGF $\beta$ signalling. High migration ability of scirrhous-type cancer cells by $\operatorname{TGF} \beta$ signalling is one of the reasons responsible for a diffusely infiltrating growth with an indistinct border from the surrounding tissue. Scirrhous carcinomas carry a worse prognosis than other types of gastric carcinomas, reflecting a high frequency of metastasis (Otsuji et al, 2004; Ikeguchi et al, 2009). Previous studies have reported that the phenotypes of metastatic cancer cells are associated with migration ability (Jung et al, 2006; Revenu and Gilmour, 2009). The different response in TGF- $\beta / \mathrm{T} \beta \mathrm{R}$ signalling between scirrhous types and non-scirrhous types might explain the poorer prognosis of scirrhous-type gastric cancers compared with non-scirrhous-types of gastric cancers.

Transforming growth factor- $\beta$ is produced not only by scirrhous gastric cancer cells (Yoshida et al, 1989; Niki et al, 2000) but also by cancer-associated fibroblasts (Mizoi et al, 1993; Inoue et al, 1997; Zeisberg et al, 2007). Our preliminary study recognised that both scirrhous gastric cancer cell lines and gastric fibroblasts produced TGF- $\beta$ (Yashiro et al, 1996b; Inoue et al, 1997). These 

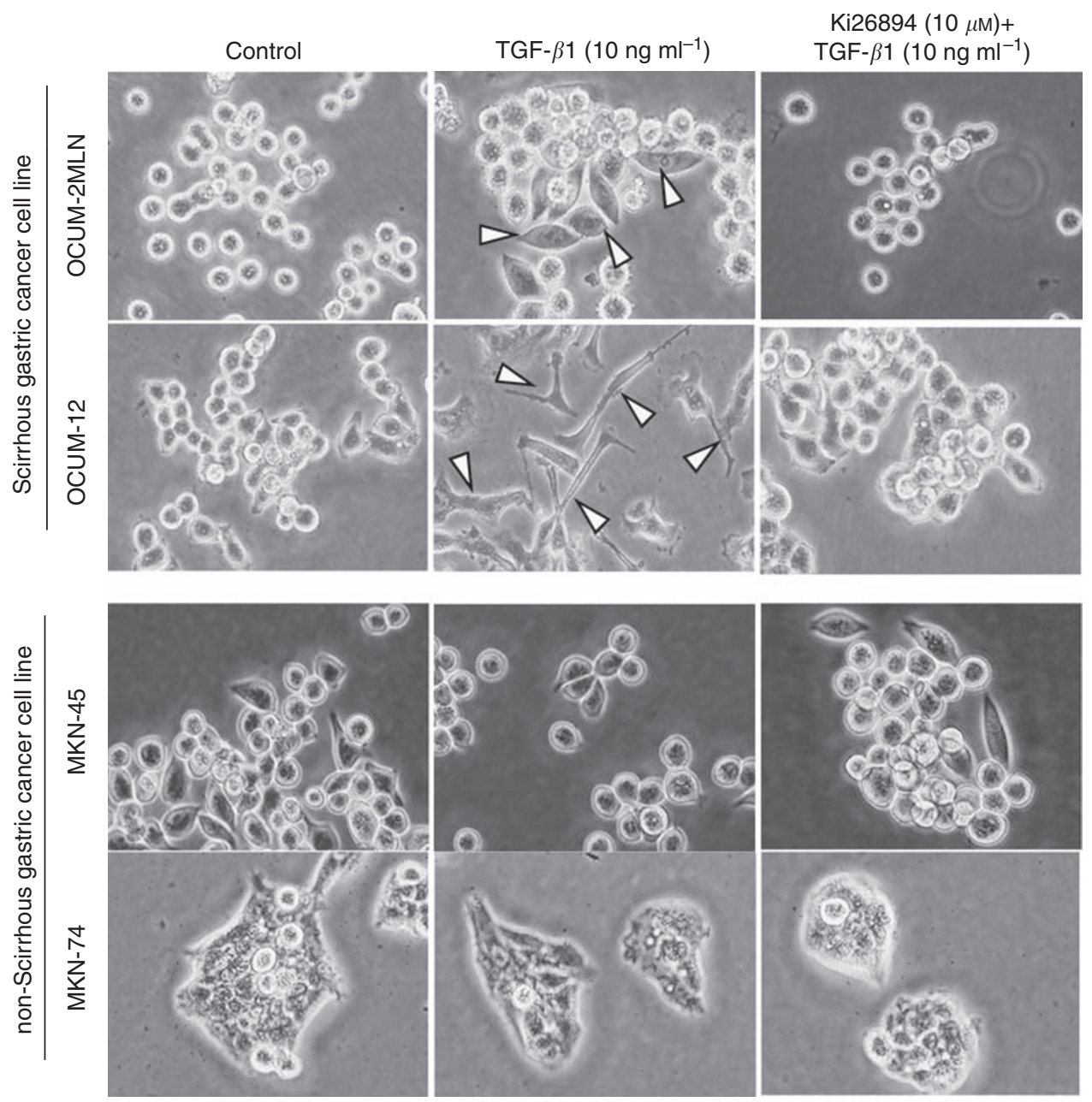

Figure 4 Effects of TGF- $\beta$ I and Ki26894 on morphological characteristics of gastric cancer cells. Epithelial-to-mesenchymal transition (arrow heads) by TGF- $\beta \mid\left(\mid 0 \mathrm{ng} \mathrm{ml}^{-1}\right)$ was shown in scirrhous gastric cancer cell lines, OCUM-2MLN and OCUM-12, but not in non-scirrhous gastric cancer cell lines, MKN-45 and MKN-74. Pseudopod formation was remarkable in OCUM-I2 cells in the presence of TGF- $\beta$ I. Epithelial-to-mesenchymal transition by TGF- $\beta$ I in scirrhous gastric cancer cells was inhibited by Ki26894 (I $0 \mu \mathrm{M})$.

findings suggest that the invasive capacity induced by TGF- $\beta$ may be influenced in both an autocrine and paracrine manner. Tumour cells in scirrhous carcinoma produce more $\operatorname{TGF} \beta$, which is a key mediator of fibroblast activation, than those in non-scirrhous carcinoma (Yoshida et al, 1989; Mahara et al, 1994). Scirrhous gastric carcinoma is characterised by cancer cell infiltration accompanied by extensive stromal fibrosis (Yashiro et al, 1996a). The typical histological findings of rapid infiltration with fibrosis might indicate that the surrounding stromal fibroblasts contribute to cancer progression more intensely in scirrhous gastric cancer than in non-scirrhous gastric cancer.

Specific small molecules designed to inhibit the effects of TGF- $\beta$ at the level of signalling receptors may be a promising strategy for patients with advanced gastric carcinoma. In this study, a T $\beta$ R-I inhibitor, Ki26894, displayed inhibitory activity against phosphorylation of Smad2 in scirrhous gastric cancer, suggesting that the small-molecule compound Ki26894 is a potent $\mathrm{T} \beta \mathrm{R}$ kinase inhibitor. Migration and invasion stimulated by TGF- $\beta$ were significantly inhibited by Ki26894 in scirrhous gastric cancer cells. In contrast, the migration and invasion by non-scirrhous cancer cells were not affected by TGF- $\beta 1$ or by Ki26894. Cell motility and invasion are critical metastatic events in cancer progression (Ehata et al, 2007). Ki26894, a small molecule designed to inhibit $\mathrm{T} \beta \mathrm{R}$, might be a promising therapeutic agent for antagonising the metastatic phenotypes seen through autocrine TGF- $\beta / \mathrm{T} \beta \mathrm{R}$ signalling in scirrhous gastric cancer. We previously reported that the $\mathrm{T} \beta \mathrm{R}$ inhibitor, A-77, decreased the expression of integrins in cancer cells, which resulted in a decreased adhesion of scirrhous gastric cancer cells to peritoneum (Kawajiri et al, 2008). Furthermore, Ki26894 inhibited the upregulation of active RhoA and phosphomyosin and inhibited the downregulation of E-cadherin and ZO-2 expression in scirrhous gastric cancer cells. Invasion by scirrhous gastric cancer cells may be inhibited by a $\mathrm{T} \beta \mathrm{R}$ inhibitor through regulation of RhoA, myosin, E-cadherin, and ZO-2 expression. These findings suggested that inhibition of the biological effects of TGF- $\beta$ might affect the adhesion, migration, and invasion of cancer cells and may be an attractive strategy for prevention of distant metastasis by scirrhous gastric cancers.

In conclusion, TGF $\beta$ signalling stimulated the EMT and invasion ability of scirrhous gastric cancer cells through regulation of RhoA, myosin, ZO-2, and E-cadherin. Ki26894, which inhibits T $\beta$ R-I phosphorylation, significantly inhibited invasion by scirrhous gastric cancer cells. The $\mathrm{T} \beta \mathrm{R}$ might be a promising target molecule for the treatment of scirrhous gastric carcinoma. 
A

A Active RhoA
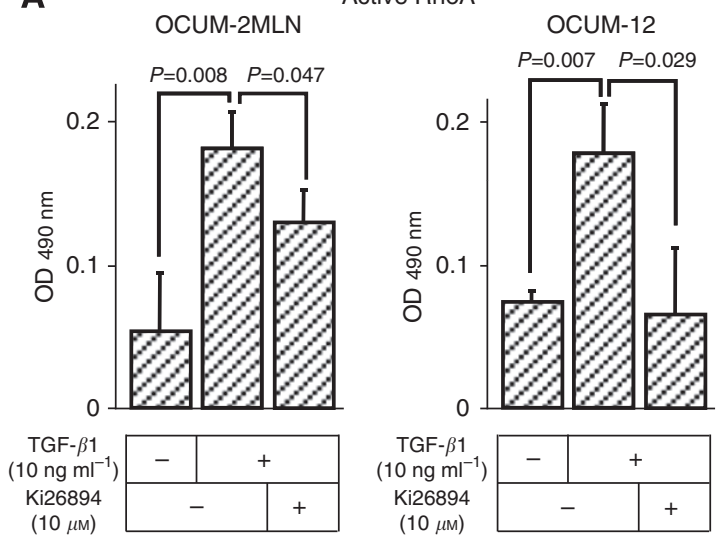

B
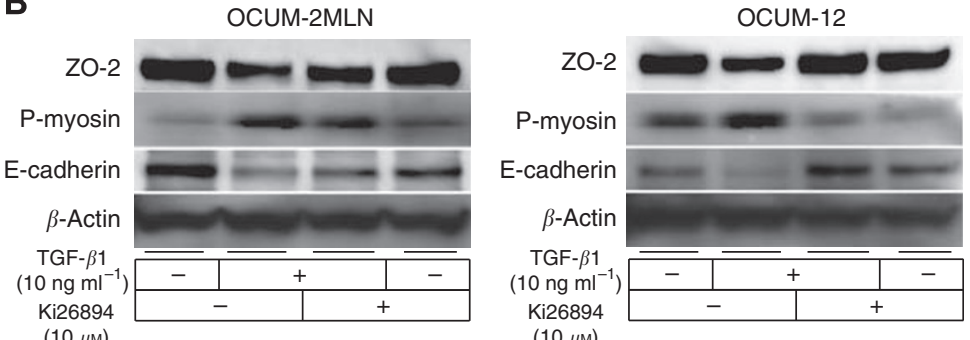

(10

$(10 \mu \mathrm{m})$

MKN-74
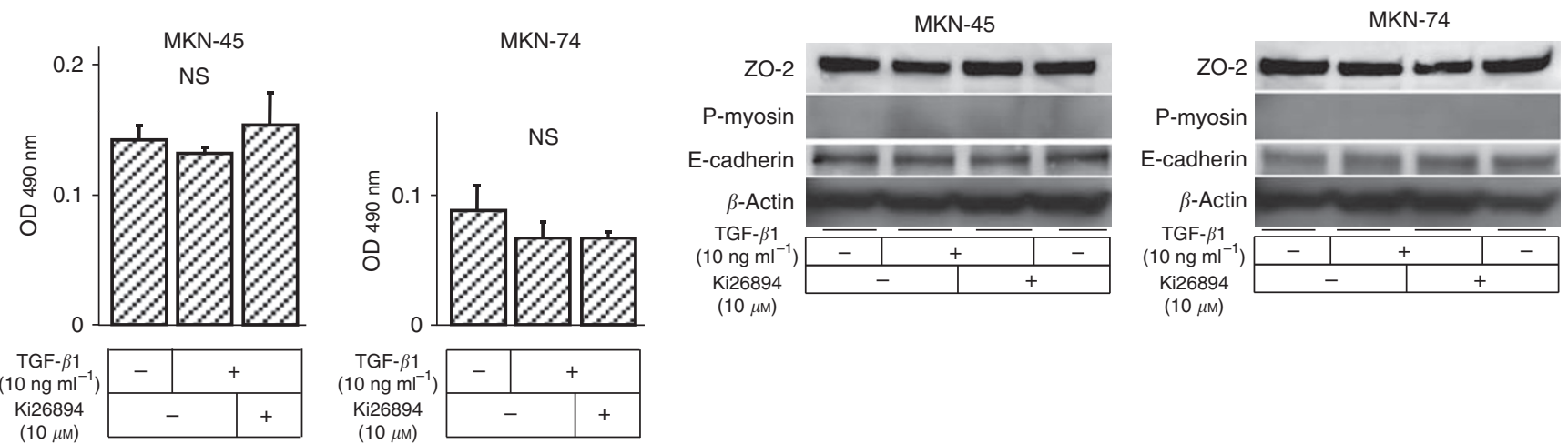

$(10 \mu \mathrm{M})$

$(10 \mu \mathrm{M})$

Figure 5 Effects of Ki26894 on cellular migration signals in gastric cancer cells. (A) ELISA of RhoA. Transforming growth factor- $\beta \mid$ ( 10 ng ml ${ }^{-1}$ ) significantly upregulated the active form of RhoA in scirrhous gastric cancer cell lines, OCUM-2MLN and OCUM-I2, and Ki26894 (I0 $\mu$ M) significantly inhibited this effect. In contrast, the active form of RhoA was not increased by TGF- $\beta$ I or by Ki26894 in non-scirrhous cancer cell lines, MKN-45 and MKN-74. (B) Transforming growth factor- $\beta \mid\left(\mid 0 \mathrm{ng} \mathrm{ml}{ }^{-1}\right)$ increased myosin light chain-2 phosphorylation ( $\mathrm{p}-\mathrm{my}$-sin) and decreased ZO-2 and E-cadherin expression in scirrhous gastric cancer cell lines, but not in non-scirrhous gastric cancer cell lines. Ki26894 (I0 $\mu \mathrm{M}$ ) decreased p-myosin, and increased ZO-2 and E-cadherin expression in scirrhous gastric cancer cell lines.

\section{ACKNOWLEDGEMENTS}

We thank professor Kohei Miyazono (Department of Molecular Pathology, Graduate School of Medicine, The University of Tokyo, Japan) for helpful advice. This study was supported in part by Grants-in Aid for Scientific Research (nos. 18591475, 20591073,

\section{REFERENCES}

Albini A, Iwamoto Y, Kleinman HK, Martin GR, Aaronson SA, Kozlowski JM, McEwan RN (1987) A rapid in vitro assay for quantitating the invasive potential of tumor cells. Cancer Res 47: 3239-3245

Borensztajn K, Stiekema J, Nijmeijer S, Reitsma PH, Peppelenbosch MP, Spek CA (2008) Factor Xa stimulates proinflammatory and profibrotic responses in fibroblasts via protease-activated receptor-2 activation. Am J Pathol 172: 309-320

Chang YW, Bean RR, Jakobi R (2009) Targeting RhoA/Rho kinase and p21-activated kinase signaling to prevent cancer development and progression. Recent Patents on Anti-Cancer Drug Discovery 4: 110-124

Ehata S, Hanyu A, Fujime M, Katsuno Y, Fukunaga E, Goto K, Ishikawa Y, Nomura K, Yokoo H, Shimizu T, Ogata E, Miyazono K, Shimizu K, Imamura T (2007) Ki26894, a novel transforming growth factor-beta type I receptor kinase inhibitor, inhibits in vitro invasion and in vivo bone metastasis of a human breast cancer cell line. Cancer Sci 98: $127-133$

Fan L, Sebe A, Peterfi Z, Masszi A, Thirone AC, Rotstein OD, Nakano H, McCulloch CA, Szaszi K, Mucsi I, Kapus A (2007) Cell contact-dependent regulation of epithelial-myofibroblast transition via the rho-rho kinasephospho-myosin pathway. Mol Biol Cell 18: 1083-1097 and 18390369) from the Ministry of Education, Science, Sports, Culture and Technology of Japan.

Supplementary Information accompanies the paper on British Journal of Cancer website (http://www.nature.com/bjc)
Fujihara T, Yashiro M, Inoue T, Sawada T, Kato Y, Ohira M, Nishiguchi Y, Ishikawa T, Sowa M, Chung KH (1999) Decrease in ICAM-1 expression on gastric cancer cells is correlated with lymph node metastasis. Gastric Cancer 2: $221-225$

Heldin CH, Miyazono K, ten Dijke P (1997) TGF-beta signalling from cell membrane to nucleus through SMAD proteins. Nature 390: $465-471$

Horiguchi K, Shirakihara T, Nakano A, Imamura T, Miyazono K, Saitoh M (2009) Role of Ras signaling in the induction of snail by transforming growth factor-beta. J Biol Chem 284: 245-253

Ikeguchi M, Miyake T, Matsunaga T, Yamamoto M, Fukumoto Y, Yamada Y, Fukuda K, Saito H, Tatebe S, Tsujitani S (2009) Recent results of therapy for scirrhous gastric cancer. Surg Today 39: $290-294$

Inoue T, Chung YS, Yashiro M, Nishimura S, Hasuma T, Otani S, Sowa M (1997) Transforming growth factor-beta and hepatocyte growth factor produced by gastric fibroblasts stimulate the invasiveness of scirrhous gastric cancer cells. Jpn J Cancer Res 88: $152-159$

Jung AC, Ribeiro C, Michaut L, Certa U, Affolter M (2006) Polychaetoid/ $\mathrm{ZO}-1$ is required for cell specification and rearrangement during Drosophila tracheal morphogenesis. Curr Biol 16: 1224-1231 
Kano MR, Bae Y, Iwata C, Morishita Y, Yashiro M, Oka M, Fujii T, Komuro A, Kiyono K, Kaminishi M, Hirakawa K, Ouchi Y, Nishiyama N, Kataoka K, Miyazono K (2007) Improvement of cancer-targeting therapy, using nanocarriers for intractable solid tumors by inhibition of TGF-beta signaling. Proc Natl Acad Sci USA 104: 3460-3465

Kawajiri H, Yashiro M, Shinto O, Nakamura K, Tendo M, Takemura S, Node M, Hamashima Y, Kajimoto T, Sawada T, Ohira M, Hirakawa K (2008) A novel transforming growth factor beta receptor kinase inhibitor, A-77, prevents the peritoneal dissemination of scirrhous gastric carcinoma. Clin Cancer Res 14: 2850-2860

Kinugasa S, Abe S, Tachibana M, Hishikawa Y, Yoshimura H, Monden N, Dhar DK, Nagasue N, Nagaoka S (1998) Overexpression of transforming growth factor-betal in scirrhous carcinoma of the stomach correlates with decreased survival. Oncology 55: 582-587

Komuro A, Yashiro M, Iwata C, Morishita Y, Johansson E, Matsumoto Y, Watanabe A, Aburatani H, Miyoshi H, Kiyono K, Shirai YT, Suzuki HI, Hirakawa K, Kano MR, Miyazono K (2009) Diffuse-type gastric carcinoma: progression, angiogenesis, and transforming growth factor beta signaling. J Natl Cancer Inst 101: $592-604$

Kunisaki C, Shimada H, Nomura M, Matsuda G, Otsuka Y, Ono H, Akiyama H (2005) Therapeutic strategy for scirrhous type gastric cancer. Hepatogastroenterology 52: 314-318

Lauren P (1965) The two histological main types of gastric carcinoma: diffuse and so-called intestinal-type carcinoma. An attempt at a histoclinical classification. Acta Pathol Microbiol Scand 64: 31-49

Mahara K, Kato J, Terui T, Takimoto R, Horimoto M, Murakami T, Mogi Y, Watanabe N, Kohgo Y, Niitsu Y (1994) Transforming growth factor beta 1 secreted from scirrhous gastric cancer cells is associated with excess collagen deposition in the tissue. Br J Cancer 69: 777-783

Massague J (2008) TGFbeta in cancer. Cell 134: 215-230

Mizoi T, Ohtani H, Miyazono K, Miyazawa M, Matsuno S, Nagura H (1993) Immunoelectron microscopic localization of transforming growth factor beta 1 and latent transforming growth factor beta 1 binding protein in human gastrointestinal carcinomas: qualitative difference between cancer cells and stromal cells. Cancer Res 53: 183-190

Motoyama T, Hojo H, Watanabe H (1986) Comparison of seven cell lines derived from human gastric carcinomas. Acta Pathol Jpn 36: 65-83

Nakazawa K, Yashiro M, Hirakawa K (2003) Keratinocyte growth factor produced by gastric fibroblasts specifically stimulates proliferation of cancer cells from scirrhous gastric carcinoma. Cancer Res 63: 8848-8852

Niki M, Toyoda M, Nomura E, Shinohara H, Nakamura M, Nishiguchi K, Tanigawa N (2000) Expression of transforming growth factor beta (TGF-beta) may contribute, in part, to the variations in histogenesis and the prevalence of peritoneal dissemination in human gastric carcinoma. Gastric Cancer 3: 187-192

Otsuji E, Kuriu Y, Okamoto K, Ochiai T, Ichikawa D, Hagiwara A, Yamagishi $\mathrm{H}$ (2004) Outcome of surgical treatment for patients with scirrhous carcinoma of the stomach. Am J Surg 188: 327-332
Qiu H, Yashiro M, Shinto O, Matsuzaki T, Hirakawa K (2009) DNA methyltransferase inhibitor 5-aza-CdR enhances the radiosensitivity of gastric cancer cells. Cancer Sci 100: $181-188$

Revenu C, Gilmour D (2009) EMT 2.0: shaping epithelia through collective migration. Curr Opin Genet Dev 19: 338-342

Romero D, Iglesias M, Vary CP, Quintanilla M (2008) Functional blockade of Smad4 leads to a decrease in beta-catenin levels and signaling activity in human pancreatic carcinoma cells. Carcinogenesis 29: $1070-1076$

Saito H, Tsujitani S, Oka S, Kondo A, Ikeguchi M, Maeta M, Kaibara N (2000) An elevated serum level of transforming growth factor-beta 1 (TGF-beta 1) significantly correlated with lymph node metastasis and poor prognosis in patients with gastric carcinoma. Anticancer Res 20: $4489-4493$

Shook D, Keller R (2003) Mechanisms, mechanics and function of epithelial-mesenchymal transitions in early development. Mech Dev 120: $1351-1383$

Takaishi K, Sasaki T, Kotani H, Nishioka H, Takai Y (1997) Regulation of cell-cell adhesion by rac and rho small G proteins in MDCK cells. J Cell Biol 139: 1047 - 1059

Tateishi M, Kusaba I, Masuda H, Tanaka T, Matsumata T, Sugimachi K (2000) The progression of invasiveness regarding the role of transforming growth factor beta receptor type II in gastric cancer. Eur J Surg Oncol 26: $377-380$

Thiery JP (2002) Epithelial-mesenchymal transitions in tumour progression. Nat Rev Cancer 2: $442-454$

Yamazaki Y, Umeda K, Wada M, Nada S, Okada M, Tsukita S, Tsukita S (2008) ZO-1- and ZO-2-dependent integration of myosin-2 to epithelial zonula adherens. Mol Biol Cell 19: 3801-3811

Yang L, Moses HL (2008) Transforming growth factor beta: tumor suppressor or promoter? Are host immune cells the answer? Cancer Res 68: $9107-9111$

Yashiro M, Chung YS, Kubo T, Hato F, Sowa M (1996a) Differential responses of scirrhous and well-differentiated gastric cancer cells to orthotopic fibroblasts. Br J Cancer 74: 1096-1103

Yashiro M, Chung YS, Nishimura S, Inoue T, Sowa M (1996b) Fibrosis in the peritoneum induced by scirrhous gastric cancer cells may act as 'soil' for peritoneal dissemination. Cancer 77: 1668-1675

Yokota T, Kunii Y, Teshima S, Yamada Y, Saito T, Takahashi M, Kikuchi S, Yamauchi H (1999) Clinicopathologic prognostic features in patients with gastric cancer associated with esophageal or duodenal invasion. Ups J Med Sci 104: 217-229

Yoshida K, Yokozaki H, Niimoto M, Ito H, Ito M, Tahara E (1989) Expression of TGF-beta and procollagen type I and type III in human gastric carcinomas. Int J Cancer 44: 394-398

Zeisberg EM, Potenta S, Xie L, Zeisberg M, Kalluri R (2007) Discovery of endothelial to mesenchymal transition as a source for carcinomaassociated fibroblasts. Cancer Res 67: 10123-10128 